\title{
Detection of Leptospira DNA in urine and presence of specific antibodies in outdoor cats in Germany
}

2017 Vol 19(4) 470-476

(c) The Author(s) 2016

Reprints and permissions:

sagepub.co.uk/journalsPermissions.nav DOI: $10.1177 / 1098612 \times 16634389$ journals.sagepub.com/home/jfms

(S)SAGE

\author{
Sonia Weis ${ }^{1}$, Anna Rettinger ${ }^{2}$, Michele Bergmann', \\ Julia R Llewellyn', Nikola Pantchev ${ }^{3}$, \\ Reinhard K Straubinger ${ }^{2}$ and Katrin Hartmann ${ }^{1}$
}

\begin{abstract}
Objectives Clinical manifestation of infection with Leptospira species in cats is rare. Nevertheless, cats can develop specific antibodies against the spirochetes after infection. In Canada, Taiwan and the USA it was recently demonstrated that naturally infected cats can also shed DNA from pathogenic Leptospira species in their urine, but the zoonotic potential of infected cats is still unclear. The objective of this study was to demonstrate if outdoor cats in Germany shed DNA from pathogenic Leptospira species in their urine. As a second aim, antibody prevalence was determined.

Methods Two hundred and fifteen outdoor cats were prospectively recruited. Urine samples were tested by realtime PCR targeting the lipL32 gene of pathogenic Leptospira species. Antibody titres against eight serovars (Australis, Autumnalis, Bratislava, Canicola, Copenhageni, Grippotyphosa, Pomona, Saxkoebing) belonging to seven serogroups (Australis, Autumnalis, Canicola, Grippotyphosa, Icterohaemorrhagiae, Pomona, Sejroe) were determined by microscopic agglutination test.

Results Urine samples from $7 / 215$ cats (3.3\%; 95\% confidence interval [Cl] 0.9-5.7) were PCR-positive. Specific antibodies were detected in 35/195 cats $(17.9 \%$; $95 \% \mathrm{Cl}: 12.5-23.3)$ with titres ranging from 1:100 to 1:6400. Australis, Bratislava and Grippotyphosa were the most common serovars.

Conclusions and relevance Outdoor cats in Germany can shed DNA from pathogenic Leptospira species. Therefore, outdoor cats should be considered as a possible source of infection for dogs or humans. Further studies are needed to determine the role of Leptospira species as a cause of disease in cats.
\end{abstract}

Accepted: 26 January 2016

\section{Introduction}

Leptospirosis is a zoonotic disease caused by pathogenic Leptospira species, an infection that has been reported in $>150$ mammalian species. ${ }^{1}$ In cats, clinical disease is rare. ${ }^{2-4}$ Nevertheless, cats are susceptible to infection and develop specific antibodies after infection. ${ }^{5-9}$ Antibody prevalence in cats ranges from $4.8-48.5 \%{ }^{7.8}$ In Germany, an antibody prevalence of $20.0 \%$ (33/165 cats) was reported in a study from 30 years ago. ${ }^{9}$ Hunting rodents is believed to be the main source of infection in cats. ${ }^{10}$ Leptospiral DNA was amplified in 288/2973 (9.7\%) rodents and shrews in Germany. ${ }^{11}$ Infection through contaminated water or urine of cohabiting dogs seems to play a minor role in cats. ${ }^{10}$

After experimental infection, cats rarely developed mild clinical signs (polyuria/polydipsia $[\mathrm{PU} / \mathrm{PD}]{ }^{12}$ rise in body temperature ${ }^{13}$ ). However, macroscopic and microscopic liver and kidney lesions were frequently reported after experimental and natural infection in cats. ${ }^{2,412}$ Two studies reported an association between the presence of specific antibodies against Leptospira

${ }^{1}$ Clinic of Small Animal Medicine, LMU Munich, Munich, Germany 2Bacteriology and Mycology, Institute for Infectious Diseases and Zoonoses, Department of Veterinary Sciences, LMU Munich, Munich, Germany

3IDEXX Laboratories, Ludwigsburg, Germany

\section{Corresponding author:}

Sonia Weis, Clinic of Small Animal Medicine, LMU Munich,

Veterinaerstraße 13, 80539 Munich, Germany

Email: soniaweis@hotmail.com 
species in cats and PU / PD or kidney disease. ${ }^{5,8}$ In France, $14 / 16(87.5 \%)$ cats with PU/PD vs $32 / 80(40.0 \%)$ cats without PU/PD had specific antibodies. ${ }^{8}$ In Canada, $17 / 114(14.9 \%)$ cats with kidney disease vs $9 / 125(7.2 \%)$ clinically healthy cats showed specific antibodies. ${ }^{5}$ However, an association between presence of antibodies and renal disease is not reported in all studies. In the USA, antibodies were found in 4/66 (6.1\%) azotaemic cats vs $8 / 75(10.7 \%)$ non-azotaemic cats. ${ }^{14}$ Although experimental infection can lead to renal lesions, the clinical relevance of leptospiral infection in field cats is still unclear. The long-term impact of leptospiral infection on cats' health also remains unknown as the longest experimental study only lasted 84 days..$^{15}$

The cats' role as carrier and the zoonotic risk of infected cats is also so far unknown. After experimental infection, cats can intermittently shed leptospires in their urine for several weeks. ${ }^{12,15}$ Recently, shedding of DNA from pathogenic Leptospira species in naturally infected cats was reported in Canada, Taiwan and the USA, ,5,6,16 with a prevalence ranging from $1.6 \%$ (in healthy cats in Canada) $)^{5}$ to $67.8 \%$ (in unselected cats in Taiwan). ${ }^{6}$ Furthermore, evidence of renal carriage in cats was reported from Reunion Island (Indian Ocean). ${ }^{17}$ In kidney samples of 6/21 (28.6\%) stray cats, DNA from pathogenic Leptospira species was detected. ${ }^{17}$ Thus, renal carriage and leptospiruria in naturally infected cats might have been underestimated. Leptospiruric cats could be a potential source of infection for incidental hosts, such as humans. ${ }^{10}$ However, in a recent study in Germany, owning an outdoor cat did not correlate with presence of Leptospira species antibodies in employees of forestry enterprises. ${ }^{18}$ In the USA, cat ownership was even negatively associated with having antibodies against Leptospira species. ${ }^{19}$ So far, prevalence of leptospiruria in cats in Germany is unknown. Thus, the first aim of this study was to show whether outdoor cats in Germany can shed DNA from pathogenic Leptospira species in their urine. As a second goal, the presence of specific antibodies in cats was evaluated.

\section{Materials and methods}

\section{Sample size calculation}

Sample size was calculated a priori using the following formula: $\mathrm{n}=\mathrm{Z}^{2} \times \mathrm{P} \times(1-\mathrm{P}) / \mathrm{d}^{2}$, with $\mathrm{n}$ being the required sample size, $\mathrm{Z}$ the standard score (for a $95 \%$ confidence interval [CI] 1.96), $P$ the expected prevalence based on literature in proportion of one and $\mathrm{d}$ the precision in proportion of one. On the basis of an assumed prevalence of leptospiral DNA shedding in cats $(11.8 \%)^{16}$ and of antibodies against Leptospira species in cats $(48.5 \%),{ }^{8}$ a sample size of 195 cats was required $(95 \%$ CI; $4.5 \%$ precision for prevalence of DNA shedding and $7.0 \%$ precision for antibody prevalence).
Cats

The study was conducted as a prospective trial and was approved by the ethical committee of the Centre for Clinical Veterinary Medicine, Ludwig-MaximiliansUniversity (LMU) of Munich, Germany (approval number: 12-30-07-13). Two hundred and fifteen cats that were presented to the Clinic of Small Animal Medicine, LMU, Munich, from July 2013 to March 2015 were included in the study. Only cats were included that were allowed to roam outdoors on a regular basis in the 4 weeks prior to presentation. Cats were presented for various clinical signs or for a routine health check. Cats that had received antibiotics within 4 weeks prior to presentation were excluded. Some cats had received intravenous (IV) fluids $(48 / 215$ cats $)$ or diuretics $(8 / 215$ cats $)$ prior to sample collection.

Most cats (190/215 cats) were domestic shorthair (DSH). Pure breeds (23/215 cats) and domestic longhairs (DLH; 2/215 cats) were less common. Eighty-three cats were female (64 neutered) and 132 cats were male (122 neutered). Ages ranged from 2 months to 24 years (median age 11 years). The age of seven cats was unknown. The most frequent reasons for presentation were gastrointestinal problems (35/215 cats), chronic kidney disease (CKD; 28/215 cats), neoplasia (25/215 cats) or a routine health check ( $24 / 215$ cats).

\section{Sample collection}

Urine samples of all cats were collected for other diagnostic purposes (urinalysis or urine culture), depending on the reason for presentation. Follow-up urine samples were examined in two PCR-positive cats. Urine samples were collected via cystocentesis (148/217 samples), free catch $(65 / 217$ samples) or urinary catheter $(4 / 217$ samples). Sample volumes ranged from $1-50 \mathrm{ml}$ (median volume $4.5 \mathrm{ml}$ ). Urine samples were stored at $4^{\circ} \mathrm{C}$ for a maximum of $24 \mathrm{~h}$ after collection.

Blood samples were collected from 195/215 cats and were stored as serum at $-20^{\circ} \mathrm{C}$ until used.

\section{DNA extraction}

Each urine sample was transferred into one or more Eppendorf tubes. Eppendorf tubes were centrifuged $\left(15,000 \times g, 4^{\circ} \mathrm{C}\right)$ for $10 \mathrm{mins}$, supernatants were discarded and pellets were washed with phosphate-buffered saline and transferred into a single Eppendorf tube. After a second centrifugation $\left(15,000 \times g, 4^{\circ} \mathrm{C}, 10 \mathrm{mins}\right)$, the supernatant was discarded, the pellet was resuspended with $180 \mu \mathrm{l}$ animal tissue lysis buffer (Qiagen) and stored at $-20^{\circ} \mathrm{C}$ until DNA extraction was performed.

A QIAamp DNA Micro Kit (Qiagen) was used to extract DNA from pellets, following the manufacturer's instructions (tissue protocol) except for a shorter lysis period $(1 \mathrm{~h}$ ). To elute DNA, $54 \mu \mathrm{l}$ AE buffer (Qiagen) was 
used. Negative controls were processed after every 10 samples. DNA concentration and quality were determined using the Eppendorf D30 Biophotometer.

\section{Standard curve}

A urine sample of a strictly indoor living cat was spiked with known quantities of $L$ interrogans serovars Ballum, Bratislava and Grippotyphosa. A Petroff-Hauser chamber (EMS) was used to determine the concentration of leptospires in a 2-week-old culture in liquid EllinghausenMcCullough/Johnson-Harris medium (Becton Dickinson). To obtain a final concentration of $1 \times 10^{6}$ leptospires $/ \mathrm{ml}$, the appropriate volume of each serovar was added to $1 \mathrm{ml}$ urine. Dilutions of $1 \times 10^{5}$ to $1 \times 10^{2}$ leptospires $/ \mathrm{ml}$ were prepared. DNA was extracted and target DNA fragments amplified.

\section{Real-time PCR}

Primers (forward: 5'-AAGCATTACCGCTTGTGGTG-3'; reverse: $5^{\prime}$-GAACTCCCATTTCAGCGATT-3') and TaqManprobe(FAM-5'-AAAGCCAGGACAAGCGCCG3'-BHQ1) targeting the lipL32 gene of pathogenic Leptospira species, as described by Stoddard et al, ${ }^{20}$ were used. Real-time PCR was performed using the Mx3000P cycler (Agilent Technologies) and TaqMan Universal PCR Master Mix (Thermo Fisher Scientific). Final reaction conditions were $900 \mathrm{nmol} / 1$ of each primer, $400 \mathrm{nmol} / 1$ of the probe and $2.5 \mu \mathrm{l}$ DNA extract in a final volume of $25.0 \mu \mathrm{l}$. The amplification protocol consisted of 2 mins at $50^{\circ} \mathrm{C}, 10 \mathrm{mins}$ at $95^{\circ} \mathrm{C}$ and 45 cycles of amplification $\left(95^{\circ} \mathrm{C}\right.$ for $15 \mathrm{~s}$ and $60^{\circ} \mathrm{C}$ for $\left.60 \mathrm{~s}\right)$, finishing with a cool cycle of $25^{\circ} \mathrm{C}$ for 10 mins. Clinical specimens were tested in triplicate, dilutions of the standard curve in duplicate. Each run included a single negative control containing PCR water, single DNA extraction controls and a single positive control containing leptospiral DNA. Results were considered positive if positive cycle threshold $(\mathrm{Ct})$ values were recorded in all triplicates. Positive samples were re-amplified in a separate run including the standard curve for an absolute quantification of leptospires.

\section{Microscopic agglutination test}

A microscopic agglutination test (MAT) was performed as described by Cole et al. ${ }^{21}$ Serum samples were tested for eight serovars (Australis, Autumnalis, Bratislava, Canicola, Copenhageni, Grippotyphosa, Pomona, Saxkoebing) belonging to seven serogroups (Australis, Autumnalis, Canicola, Grippotyphosa, Icterohaemorrhagiae, Pomona, Sejroe). Two-fold dilutions of serum from 1:100 to 1:6400 were tested. The titre was recorded as the reciprocal of the highest dilution of serum that agglutinated $>50 \%$ of leptospires. Titres $\geqslant 1: 100$ were considered positive.

\section{Statistical analysis}

Prevalences, including 95\% CIs, were calculated for leptospiral DNA shedding and antibodies against Leptospira species. The $95 \% \mathrm{CI}$ was calculated using the following formula (Wald method): $\mathrm{P} \pm \mathrm{d}$, with $\mathrm{P}$ being the prevalence found in the study in proportion of one and $\mathrm{d}$ being the precision in proportion of one calculated by transposing the mentioned formula to:

$$
\mathrm{d}=\mathrm{Z} \times \sqrt{\mathrm{P} \times(1-\mathrm{P}) / \mathrm{n}} .
$$

\section{Results}

Prevalence of DNA shedding

DNA from pathogenic Leptospira species was amplified in $7 / 215$ cats $(3.3 \% ; 95 \%$ CI $0.9-5.7)$. Negative controls tested negative, positive controls and the standard curve tested positive. The number of leptospires ranged from 393-15,760 leptospires/ml (Table 1). Volumes of PCRpositive urine samples ranged from 2-22 $\mathrm{ml}$ (median volume $6.3 \mathrm{ml}$ ). Signalment, reason for presentation, major laboratory findings, month of presentation, number of leptospires/ $\mathrm{ml}$ urine (DNA copies) and MAT titres of the PCR-positive cats are shown in Table 1.

In 2/7 PCR-positive cats (cats 1 and 2, Table 1), follow-up urine samples were examined. In the case of cat 1 , urine tested negative for leptospiral DNA 9 months after the first presentation. The urine of cat 2 was positive again for leptospiral DNA 8 months after the cat's first presentation (2901 leptospires/ml). In both cases, no antibiotics were given between the first and the second presentation.

\section{Antibody prevalence}

Antibodies against Leptospira serovars were detected in 35/195 cats (17.9\%; 95\% CI 12.5-23.3). Most cats had antibodies against serogroup Australis, followed by serogroup Grippotyphosa and Icterohaemorrhagiae. Less common serogroups were Autumnalis, Sejroe and Pomona. Antibodies against serogroup Canicola were not detected. Antibody titres ranged from 1:100 to 1:6400 (Table 2).

The age of cats with antibodies ranged from 1-24 years (median age 11 years). Eleven cats with antibodies were female (10 neutered); 24 cats were male (22 neutered). Most cats with antibodies (34/35 cats) were DSH. One cat was a DLH. The most frequent reasons for presentation in cats with antibodies were CKD ( $8 / 35$ cats), neoplasia ( $7 / 35$ cats), hyperthyroidism (5/35 cats), gastrointestinal problems $(5 / 35)$ or a routine health check $(5 / 35$ cats).

High titres, of $\geqslant 1: 800$, were found in three cats against serovar Australis and in one cat against serovar Saxkoebing (Table 2). Two of three cats with high antibodies against serovar Australis shed leptospiral DNA in their urine (cats 6 and 7, Table 1). The third cat 
Table 1 Breed, sex, age, reason for presentation, major laboratory findings, month of presentation, number of leptospires/ml urine (DNA copies) and microscopic agglutination test (MAT) titres of urine PCR cats

\begin{tabular}{|c|c|c|c|c|c|c|c|c|}
\hline No. & Breed & Sex & $\begin{array}{l}\text { Age } \\
\text { (years) }\end{array}$ & $\begin{array}{l}\text { Reason for } \\
\text { presentation }\end{array}$ & $\begin{array}{l}\text { Major laboratory } \\
\text { findings (CBC, } \\
\text { clinical chemistry, } \\
\text { UA) }\end{array}$ & $\begin{array}{l}\text { Month of } \\
\text { presentation }\end{array}$ & $\begin{array}{l}\text { Leptospires/ } \\
\text { ml urine } \\
\text { (DNA } \\
\text { copies) }\end{array}$ & Titre (MAT) \\
\hline 1 & DSH & $\mathrm{MN}$ & 6 & $\begin{array}{l}\text { Routine health } \\
\text { check }\end{array}$ & Unremarkable & April & 393 & $\begin{array}{l}1: 400, \text { Australis } \\
1: 400, \text { Bratislava }\end{array}$ \\
\hline 2 & DSH & $\mathrm{MN}$ & 11 & $\begin{array}{l}\text { Mast cell tumour } \\
\text { in spleen and } \\
\text { liver }\end{array}$ & Unremarkable & July & 15,760 & $\begin{array}{l}\text { 1:100, } \\
\text { Grippotyphosa }\end{array}$ \\
\hline 3 & DSH & $\mathrm{MN}$ & 8 & $\begin{array}{l}\text { Foreign body in } \\
\text { pharynx (grass) }\end{array}$ & Unremarkable & August & 9461 & ND \\
\hline 4 & DSH & $\mathrm{MN}$ & 14 & $\begin{array}{l}\text { Severe } \\
\text { anaemia, } \\
\text { renal failure, } \\
\text { abdominal mass }\end{array}$ & $\begin{array}{l}\text { Non-regenerative } \\
\text { anaemia, azotaemia, } \\
\text { low USG }\end{array}$ & October & 1649 & $\begin{array}{l}\text { 1:400, } \\
\text { Grippotyphosa }\end{array}$ \\
\hline 5 & DSH & $\mathrm{MN}$ & 14 & $\begin{array}{l}\text { Chronic } \\
\text { diarrhoea }\end{array}$ & $\begin{array}{l}\text { Non-regenerative } \\
\text { anaemia }\end{array}$ & January & 662 & $\begin{array}{l}1: 400, \text { Australis } \\
1: 100, \text { Autumnalis } \\
1: 200, \text { Bratislava } \\
1: 200 \text {, Copenhageni }\end{array}$ \\
\hline 6 & DSH & FN & 6 & Seizures & Unremarkable & January & 1303 & 1:800, Australis \\
\hline 7 & DSH & $\mathrm{FN}$ & 1 & $\begin{array}{l}\text { Acute diarrhoea, } \\
\text { coccidiosis }\end{array}$ & $\begin{array}{l}\text { Leukocytosis } \\
\text { with left shift, } \\
\text { panhypoproteinaemia }\end{array}$ & March & 612 & $\begin{array}{l}\text { 1:800, Australis } \\
\text { 1:100, Bratislava } \\
\text { 1:100, Copenhageni }\end{array}$ \\
\hline
\end{tabular}

$\mathrm{CBC}=$ complete blood count; $\mathrm{UA}=$ urinalysis; $\mathrm{DSH}=$ domestic shorthair; $\mathrm{MN}=$ male neutered; $\mathrm{ND}=$ not determined; $\mathrm{USG}=$ urine specific gravity; $F N=$ female neutered

Table 2 Number and percentage of microscopic agglutination test (MAT)-positive results among 195 outdoor cats; 15/35 MAT-positive cats had titres to more than one serovar

\begin{tabular}{|c|c|c|c|c|c|c|c|c|c|}
\hline \multirow[t]{2}{*}{ Serogroup } & \multirow[t]{2}{*}{ Serovar } & \multicolumn{6}{|c|}{ Number of MAT titres $\geqslant 1: 100$} & \multirow{2}{*}{$\begin{array}{l}\text { Total number } \\
\text { of MAT titres } \\
\geqslant 1: 100\end{array}$} & \multirow{2}{*}{$\begin{array}{l}\text { Percentage } \\
\text { of MAT titres } \\
\geqslant 1: 100(95 \% \mathrm{Cl})\end{array}$} \\
\hline & & 1:100 & $1: 200$ & $1: 400$ & $1: 800$ & $1: 1600$ & $1: 6400$ & & \\
\hline \multirow[t]{2}{*}{ Australis } & Australis & 4 & 2 & 8 & 2 & 0 & 1 & 17 & $8.7(4.7-12.7)$ \\
\hline & Bratislava & 7 & 3 & 4 & 0 & 0 & 0 & 14 & $7.2(3.6-10.8)$ \\
\hline Autumnalis & Autumnalis & 1 & 1 & 0 & 0 & 0 & 0 & 2 & $1.0(0.0-2.4)$ \\
\hline Canicola & Canicola & 0 & 0 & 0 & 0 & 0 & 0 & 0 & 0.0 \\
\hline Grippotyphosa & Grippotyphosa & 8 & 1 & 2 & 0 & 0 & 0 & 11 & $5.6(2.4-8.8)$ \\
\hline Icterohaemorrhagiae & Copenhageni & 6 & 1 & 0 & 0 & 0 & 0 & 7 & $3.6(1.0-6.2)$ \\
\hline Pomona & Pomona & 1 & 0 & 0 & 0 & 0 & 0 & 1 & $0.5(0.0-1.5)$ \\
\hline \multirow[t]{2}{*}{ Sejroe } & Saxkoebing & 1 & 0 & 0 & 0 & 1 & 0 & 2 & $1.0(0.0-2.4)$ \\
\hline & Total & 28 & 8 & 14 & 2 & 1 & 1 & 54 & $27.7(21.4-34.0)$ \\
\hline
\end{tabular}

$\mathrm{Cl}=$ confidence interval

(DSH, 17 years, male neutered) had a very high antibody titre against serovar Australis (1:6400) and a low antibody titre against serovar Bratislava (1:400). PCR performed on urine of this cat produced negative results. The cat suffered from hyperthyroidism and CKD. One cat (DSH, 9 years, male neutered) had a high antibody titre of 1:1600 against serovar
Saxkoebing and its urine was negative in PCR testing. This cat suffered from pancreatitis with a moderate prerenal azotaemia.

All cats that shed leptospiral DNA and in which serum for antibody determination was available (6/7 shedding cats) had specific antibodies with titres ranging from 1:100 to 1:800 (Table 1). 


\section{Discussion}

More cats $(7 / 215$ cats [3.3\%, 95\% CI 0.9-5.7]) in the present study shed leptospiral DNA in their urine than dogs $(3 / 200$ dogs $[1.5 \%, 95 \%$ CI $0.3-4.5])$ in a study that was recently performed in the same area with the same PCR method. ${ }^{22}$ Leptospiruria in dogs in Germany might be less likely owing to the widespread vaccination..$^{23}$ Vaccines reduce leptospiruria; ${ }^{23}$ thus, vaccinated animals are at lower risk of shedding leptospires in their urine. Antibody prevalence, however, was similar in cats and dogs. Of 200 dogs, $17.0 \%$ (95\% CI 12.3-22.8) had antibodies against non-vaccinal serogroups, ${ }^{22}$ while of 195 cats, $17.9 \%$ (95\% CI 12.5-23.3) had antibodies. Vaccination against leptospirosis in dogs can lead to development of antibodies against both vaccinal and non-vaccinal serogroups. ${ }^{24}$ In some dogs, vaccineinduced antibodies can persist for 1 year. ${ }^{24}$ In the study that evaluated antibodies against leptospires in dogs in Germany, 144/145 dogs with known vaccination status had been vaccinated with a bivalent leptospirosis vaccine. ${ }^{22}$ Thus, antibody prevalence due to exposure in dogs might indeed be lower and exposure in cats seems to be even more common than in dogs.

Prevalence of urinary shedding in the present study $(7 / 215$ cats $[3.3 \% ; 95 \%$ CI $0.9-5.7])$ was similar to that reported in cats in Canada (8/238 cats [3.4\%])..$^{5} \mathrm{~A}$ comparable study population (clinic population) and a similar environment (mostly urban) are likely the reasons. However, in the Canadian study only 142/239 cats had outdoor access, ${ }^{5}$ while in the present study all cats roamed outdoors regularly. Consequently, cats in the present study were at higher risk of infection. A higher prevalence was reported in the USA $(10 / 85$ cats $[11.8 \%])$, but only stray and feral shelter cats were included (preselected population), ${ }^{16}$ which, of course, are more likely to feed on rodents that harbour an infection. ${ }^{5,10}$ In Taiwan, 80/118 cats (67.8\%) shed DNA from pathogenic Leptospira species in their urine, ${ }^{6}$ indicating a much higher prevalence of infection than in Germany. Leptospirosis is endemic in Taiwan, especially after typhoon and flood seasons. ${ }^{6,25}$ Additionally, 159/233 cats included in the Taiwanese study were stray cats with a high risk of infection. ${ }^{6}$ However, even the lower prevalence in Germany is alarming as significant amounts of leptospiral DNA and also multiple positive samples were detected (Table 1), suggesting a possible long-term shedding or a high risk of exposure in some cats. ${ }^{12,15}$

After experimental infection, cats can remain carriers of leptospires for several weeks. ${ }^{12,15}$ In the present study, a follow-up urine sample from one cat that shed leptospiral DNA was PCR-positive 8 months after the first presentation. Thus, shedding cats could possibly play an important role for continuous environmental contamination. However, reinfection would also have been possible in this case, as the cat regularly went outdoors.

Interestingly, two cats that shed leptospiral DNA were presented in January. In dogs, transmission is unlikely in winter months in Germany as leptospires are short-lived in stagnant waters when temperature is low. ${ }^{1,26}$ However, carriers of Leptospira species, like rodents, can be infected for their entire life, ${ }^{26}$ and thus a seasonal occurrence, although present in dogs in Germany, is less likely in cats.

The lipL32 PCR used in the present study has been shown to be $100 \%$ specific, ${ }^{20,27}$ and negative controls were consistently negative. In this study, only urine samples were considered PCR-positive, when Ct values were positive in all three samples of its triplicate. Furthermore, validity of PCR results was confirmed by the fact that all positive cats also had antibodies. Hence, false-positive PCR results are extremely unlikely. However, the prevalence found in the present study might underestimate the true infection rate of the population as intermittent shedding of leptospires is common. ${ }^{26}$ Urine volumes in this study ranged from 1-50 ml. As shedding of low numbers of leptospire organisms is possible, false-negative results might have occurred in samples with small volumes. However, median volumes of PCR-positive urine samples $(6.3 \mathrm{ml})$ were not significantly higher compared with median volumes of PCR-negative urine samples $(4.5 \mathrm{ml})$.

Some cats had received IV fluids or diuretics prior to sample collection. IV fluids or diuretics reduce urine osmolarity and might create a more favourable condition for the survival of leptospires. ${ }^{28}$ Nevertheless, none of the PCR-positive cats were treated with IV fluids or diuretics prior to sample collection.

Overall, antibody prevalence in the present study (35/195 cats [17.9\%, 95\% CI 12.5-23.3]) was comparable to antibody prevalence found in cats in Germany about 30 years ago $(33 / 165$ cats $[20.0 \%]) .{ }^{9}$ Antibodies against serogroups Autumnalis, Canicola, Grippotyphosa, Icterohaemorrhagiae, Pomona and Sejroe were determined by MAT in both the present and the previous study. ${ }^{9}$ Prevalences of antibodies to most of these serogroups were similar in both studies. However, the prevalence of antibodies to serogroup Icterohaemorrhagiae was higher in the present study (3.6\%) than in the previous one $(0.0 \%){ }^{9}$ Rats are carriers of serogroup Icterohaemorrhagiae. ${ }^{26,29}$ Accordingly, these findings suggest rats as the source of infection for cats in the present study. However, MAT results should be interpreted with caution. In humans, the predominant serogroup with a titre $\geqslant 1: 100$ correctly predicted only $46.4 \%$ of all serovars isolated. ${ }^{30}$ In dogs vaccinated against leptospirosis, crossreactivity to non-vaccinal serogroups in the MAT was demonstrated ${ }^{24}$ and there is evidence that this might be 
similar in cats. ${ }^{14}$ In a recent study, two specific pathogenfree cats were vaccinated with a quadrivalent canine vaccine against leptospirosis. Both cats developed antibodies against vaccinal and non-vaccinal serogroups. ${ }^{14}$ It is likely that in naturally infected cats MAT results are also not reliable for identification of the infecting serogroup.

Cats that shed leptospiral DNA in the present study were either clinically healthy $(1 / 7$ cats) or showed various clinical signs (6/7 cats). Most cats (4/7 cats) had unremarkable laboratory parameters. Only $1 / 7$ cats suffered from renal azotaemia (Table 1). Thus, obviously cats can shed leptospiral DNA in their urine, regardless of their health status. In the present study, 5/24 (20.8\%, 95\% CI 4.6-37.0) clinically healthy cats and $8 / 28(28.6 \%, 95 \%$ CI 11.9-45.3) cats with CKD had antibodies against Leptospira species. Therefore, in the present study no association seemed to be present between occurrence of antibodies against Leptospira species and renal disease. However, re-evaluation in further studies is recommended as sample sizes of healthy cats and cats suffering from CKD in the present study were low.

Two of the four cats with high titres, of $\geqslant 1: 800$, also shed leptospiral DNA in their urine. Urine samples of the two other cats with titres $\geqslant 1: 800$ were PCR-negative. These negative results can be explained by intermittent shedding as intermittent shedding of leptospires is a common finding. ${ }^{26}$ Furthermore, false-negative results are possible in these two cats due to relatively small urine volumes examined $(1.5 \mathrm{ml}$ and $5.0 \mathrm{ml}$, respectively).

Limitations of this study are that follow-up urine samples could only be obtained in $2 / 7$ cats that shed leptospiral DNA. In this study, DNA from pathogenic Leptospira species was detected, which cannot predict viability of leptospires. The viability of leptospires in the cats' urine and the zoonotic potential of the shedding cats has to be further elucidated.

\section{Conclusions}

Prevalence of shedding of DNA from pathogenic Leptospira species in outdoor cats in Germany was 3.3\%, while the prevalence of specific antibodies was $17.9 \%$. As a result, outdoor cats in Germany are exposed to leptospires and regularly shed leptospiral DNA. The role of cats as a source of infection likely has been underestimated and the zoonotic risk of shedding cats, as well as the potential of leptospires to cause disease in cats, has to be further elucidated.

Acknowledgements We are grateful for the statistical support provided by Dr med vet Sven Reese (Institute of Veterinary Anatomy, LMU Munich).

Conflict of interest The authors declared no potential conflicts of interest with respect to the research, authorship, and/ or publication of this article.
Funding The authors received no financial support for the research, authorship, and/or publication of this article.

\section{References}

1 Sykes JE, Hartmann K, Lunn KF, et al. 2010 ACVIM small animal consensus statement on leptospirosis: diagnosis, epidemiology, treatment, and prevention. J Vet Intern Med 2011; 25: 1-13.

2 Arbour J, Blais MC, Carioto L, et al. Clinical leptospirosis in three cats (2001-2009). J Am Anim Hosp Assoc 2012; 48: 256-260.

3 Beaudu-Lange $C$ and Lange E. Unusual clinical presentation of leptospirosis in a cat. Rev Vet Clin 2014; 49: 115-122.

4 Bryson DG and Ellis WA. Leptospirosis in a British domestic cat. J Small Anim Pract 1976; 17: 459-465.

5 Rodriguez J, Blais MC, Lapointe C, et al. Serologic and urinary PCR survey of leptospirosis in healthy cats and in cats with kidney disease. J Vet Intern Med 2014; 28 : 284-293.

6 Chan KW, Hsu YH, Hu WL, et al. Serological and PCR detection of feline Leptospira in Southern Taiwan. Vector Borne Zoonotic Dis 2014; 14: 118-123.

7 Markovich JE, Ross L and McCobb E. The prevalence of leptospiral antibodies in free roaming cats in Worcester County, Massachusetts. J Vet Intern Med 2012; 26: 688-689.

8 Luciani O. Réceptivité et sensibilité du chat aux leptospires [thesis in French]. National Veterinary School of Nantes, 2004.

9 Bätza HJ and Weiss R. Zum Vorkommen von LeptospiraAntikörpern in Katzenseren [in German]. Kleintierpraxis 1987; 32: 171-172.

10 Hartmann K, Egberink H, Pennisi MG, et al. Leptospira species infection in cats: $A B C D$ guidelines on prevention and management. J Feline Med Surg 2013; 15: 576-581.

11 Mayer-Scholl A, Hammerl JA, Schmidt S, et al. Leptospira spp. in rodents and shrews in Germany. Int J Environ Res Public Health 2014; 11: 7562-7574.

12 Fessler JF and Morter RL. Experimental feline leptospirosis. Cornell Vet 1964; 54: 176-190.

13 Shophet R and Marshall RB. An experimentally induced predator chain transmission of Leptospira ballum from mice to cats. Br Vet J 1980; 136: 265-270.

14 Shropshire SB, Veir JK, Morris AK, et al. Evaluation of the Leptospira species microscopic agglutination test in experimentally vaccinated cats and Leptospira species seropositivity in aged azotemic client-owned cats. J Feline Med Surg 2016; 18: 768-772.

15 Larsson CE, Santa Rosa CA, Larsson MH, et al. Laboratory and clinical features of experimental feline leptospirosis. Int J Zoonoses 1985; 12: 111-119.

16 Fenimore A, Carter K and Lunn KF. Detection of leptospiruria in shelter cats in Colorado [abstract]. J Vet Intern Med 2012; 26: 783.

17 Desvars A, Naze F, Benneveau A, et al. Endemicity of leptospirosis in domestic and wild animal species from Reunion Island (Indian Ocean). Epidemiol Infect 2013; 141: 1154-1165.

18 Jurke A, Bannert N, Brehm K, et al. Serological survey of Bartonella spp., Borrelia burgdorferi, Brucella spp., Coxiella burnetii, Francisella tularensis, Leptospira spp., Echinococcus, 
Hanta-, TBE- and XMR-virus infection in employees of two forestry enterprises in North Rhine-Westphalia, Germany, 2011-2013. Int J Med Microbiol 2015; 305: 652-662.

19 Childs JE, Schwartz BS, Ksiazek TG, et al. Risk factors associated with antibodies to leptospires in inner-city residents of Baltimore: a protective role for cats. Am J Public Health 1992; 82: 597-599.

20 Stoddard RA, Gee JE, Wilkins PP, et al. Detection of pathogenic Leptospira spp. through TaqMan polymerase chain reaction targeting the LipL32 gene. Diagn Microbiol Infect Dis 2009; 64: 247-255.

21 Cole JR, Jr, Sulzer CR and Pursell AR. Improved microtechnique for the leptospiral microscopic agglutination test. Appl Microbiol 1973; 25: 976-980.

22 Llewellyn JR, Krupka-Dyachenko I, Rettinger AL, et al. Prevalence of Leptospira urinary shedding in healthy dogs from Southern Germany [abstract]. J Vet Intern Med 2014; $28: 727$.

23 Schreiber P, Martin V, Najbar W, et al. Prevention of renal infection and urinary shedding in dogs by a Leptospira vaccination. Vet Microbiol 2005; 108: 113-118.
24 Martin LE, Wiggans KT, Wennogle SA, et al. Vaccine-associated Leptospira antibodies in client-owned dogs. $J$ Vet Intern Med 2014; 28: 789-792.

$25 \mathrm{Su}$ HP, Chan TC and Chang CC. Typhoon-related leptospirosis and melioidosis, Taiwan, 2009. Emerg Infect Dis 2011; 17: 1322-1324.

26 Levett PN. Leptospirosis. Clin Microbiol Rev 2001; 14: 296-326.

27 Fink JM, Moore GE, Landau R, et al. Evaluation of three 5 ' exonuclease-based real-time polymerase chain reaction assays for detection of pathogenic Leptospira species in canine urine. J Vet Diagn Invest 2015; 27: 159-166.

28 Nervig RM and Garrett LA. Use of furosemide to obtain bovine urine samples for leptospiral isolation. Am J Vet Res 1979; 40: 1197-1200.

29 Bharti AR, Nally JE, Ricaldi JN, et al. Leptospirosis: a zoonotic disease of global importance. Lancet Infect Dis 2003; 3: 757-771.

30 Levett PN. Usefulness of serologic analysis as a predictor of the infecting serovar in patients with severe leptospirosis. Clin Infect Dis 2003; 36: 447-452. 